\title{
INTERNATIONAL APPROACHES TO CLIMATE CHANGE AND CULTURAL HERITAGE
}

\author{
George Hambrecht and Marcy Rockman
}

\begin{abstract}
Anthropogenic climate change is increasingly threatening cultural heritage; cultural resource managers, communities, and archaeologists are confronting this reality. Yet the phenomenon is happening over such a wide range of physical and sociocultural contexts that it is a problem too big for any one organization or discipline to tackle. Therefore, the sharing of best practices and examples between the communities dealing with this problem is essential. This article presents examples from communities, cultural resource managers, and archaeologists who are engaging with climate change-based threats to cultural heritage. Our presentation of these international activities follows the US National Park Service (NPS) four-pillar approach to climate-change threats to cultural heritage: science, mitigation, adaptation, and communication. We discuss this approach and then present a number of cases in which communities or institutions are attempting to manage cultural heritage threatened by climate change through these four pillars. This article restricts itself to examples that are taking place outside of the USA and concludes with some general recommendations for both archaeologists and funding entities.
\end{abstract}

El cambio climático antropogénico amenaza cada vez más el patrimonio cultural; los gerentes de recursos culturales, las comunidades y los arqueólogos se enfrentan a esta realidad. Sin embargo, dada la ocurrencia de este fenómeno en tan amplia gama de contextos físicos y socioculturales, es un problema demasiado grande para una sola organización o disciplina. Por eso, es esencial compartir mejores prácticas y ejemplos entre las comunidades que hacen frente a este problema. Este artículo presenta ejemplos tomados de comunidades, gerentes de recursos culturales y arqueólogos quienes están respondiendo a amenazas al patrimonio cultural relacionadas con el cambio climático. Nuestra presentación de estas actividades internacionales sigue el enfoque del National Park Service de los Estados Unidos hacia la amenaza del cambio climático al patrimonio cultural, que identifica cuatro pilares: ciencia, mitigación, adaptación y comunicación. Discutimos este enfoque y luego presentamos varios casos en los que comunidades o instituciones están tratando de administrar el patrimonio cultural amenazado por el cambio climático usando estos cuatro pilares. Este artículo se limita a ejemplos que están teniendo lugar fuera de los Estados Unidos y concluye con recomendaciones tanto para los arqueólogos como para las entidades financiadoras.

Climate change-based threats to cultural heritage will do extensive damage to our shared human historical inheritance. Damage to a cultural heritage site can mean the loss of irreplaceable cultural, social, and economic assets to local, national, and global communities. The multitude of uses that cultural heritage serves in society are threatened by climate change, from the formation of community identities to the financial returns of tourism (Markham et al. 2016; Scott et al. 2016). Cultural resource managers, communities, and archaeologists confront this reality, yet the phenomenon is happening at such a wide global scale and within so many contexts, both physical and sociocultural, that it is a problem too big for any one organization or discipline to tackle. Therefore, the sharing of best practices and examples between the myriad communities dealing with this problem is essential. This article presents examples from communities, cultural resource managers, and archaeologists who are engaging with climate change-based threats to cultural heritage. This article restricts itself to non-US examples, and is the product of

George Hambrecht - Anthropology Department, University of Maryland, College Park, 0111 Woods Hall, 4302 Chapel Drive, College Park, MD, 20742, USA (ghambrec@umd.edu, corresponding author)

Marcy Rockman $\square$ Climate Change Adaptation Coordinator for Cultural Resources, National Park Service, 1201 Eye St. NW, Washington, DC 20005, USA

American Antiquity 82(4), 2017, pp. 627-641

Copyright (C) 2017 by the Society for American Archaeology. This is an Open Access article, distributed under the terms of the Creative Commons Attribution licence (http://creativecommons.org/licenses/by/4.0/), which permits unrestricted reuse, distribution, and reproduction in any medium, provided the original work is properly cited.

doi:10.1017/aaq.2017.30 
collaboration between the University of Maryland College Park, Anthropology Department and the US National Park Service (NPS) Climate Change Adaptation Coordinator for Cultural Resources. This collaboration aims to assist in the production of the NPS Cultural Resources Climate Change Strategy (Rockman et al. 2016, see Goal 4: Learn and Share). One facet of this collaboration was to look out towards the rest of the world and take stock of what other national governments, non-governmental organizations (NGOs), cultural resource managers, and local communities were doing on the ground to help monitor, adapt to, mitigate against, and communicate about climate threats to cultural heritage. This article is a digest of these efforts. It highlights the dangers of climate change to cultural heritage by emphasizing its global context, and it encourages dialogue among and provides resources to cultural heritage stakeholders in the United States.

\section{Background}

Climate-change threats to cultural heritage sites are increasingly recognized as a threat to society at large (Cassar 2005; Erlandson 2008; Fitzpatrick et al. 2015; Harvey and Perry 2015; Markham and Wiser 2015; Marzeion and Levermann 2014; Rockman 2015). Within the United States, the NPS recognition of this threat is evident in its creation of the program for cultural resources within the NPS Climate Change Response Program and subsequent development of relevant policies and guidance (Markham et al. 2016; Morgan et al. 2016; National Park Service 2014; Rockman et al. 2016; Schupp et al. 2016). An overview of major cultural heritage and climate-change projects of other US federal agencies and NGO partners is included in Rockman et al. (2016). Within the larger scientific community one of the most recent products in response to this threat is the Pocantico Call to Action on Climate Impacts and Cultural Heritage Declaration by the Union of Concerned Scientists, formulated in 2015 (Union of Concerned Scientists 2015). Recognition is also manifest within the academic and cultural resources management communities, as evidenced by Society for American Archaeology's formation of the
Climate Change Strategies and Archaeological Resources Committee in 2016, of which the authors are members.

Major international organizations that have cultural heritage within their remit were among the first to recognize the threats that climate change poses to cultural heritage. UN-based and UN-affiliated organizations for cultural heritage, such as the World Heritage Centre of UNESCO (2017) have issued calls to action in regards to climate-change threats to cultural heritage for the last decade. The World Heritage Committee's 2006 Vilnius Declaration serves as a grand international statement of the problem, and subsequent managerial handbooks have further defined the issue as well as approaches to handling specific threats. UNESCO's efforts have focused on implementation through the International Center for the Study of the Preservation and Restoration of Cultural Property (ICCROM). ICCROM includes climate-change threats to cultural heritage within its Disaster and Risk Management focus (ICCROM 2017). Among international NGOs, the US chapter of the International Council on Monuments and Sites (US ICOMOS) has set Heritage and Climate Change as one of its five major themes of knowledge exchange (US ICOMOS 2017).

On a national scale, governmental organizations have produced documents concerned with climate impacts on cultural heritage. Historic England's Assessment of Heritage at Risk from Environmental Threat (Historic England 2013), which is part of Historic England's National Heritage Protection Plan, is an example. Historic Environment Scotland's A Climate Change Action Plan for Historic Scotland 2012-2017 is another, as is the Australian Departments of Climate Change and of the Environment, Water, Heritage, and the Arts 2009 study, Implications of Climate Change for Australia's World Heritage Properties: A Preliminary Assessment (Australian Government Department of Climate Change 2009; Historic Scotland 2012).

\section{The NPS Four-Pillar Approach}

The NPS Climate Change Response Strategy (National Park Service 2010) sets out four primary pillars for management of protected 
areas: science, adaptation, mitigation, and communication. In this scheme, the science pillar collects all work undertaken to gather climaterelevant data (e.g., measurements, modeling, and related techniques). Adaptation combines efforts to determine what to do about climate change, including policy, guidance, and approaches to planning and decision making. Mitigation refers to efforts to reduce greenhouse gas emissions. ${ }^{1}$ Communication incorporates efforts to share information in a meaningful and useful manner, both among resource managers and with the public.

For cultural resources specifically, the NPS has created an approach in its 2014 Director's Policy Memo Climate Change and the Stewardship of Cultural Resources (National Park Service 2014):

cultural resource management must keep in mind that (1) cultural resources are primary sources of data regarding human interactions with environmental change; and (2) changing climates affect the preservation and maintenance of cultural resources.

We refer to these two approaches as (1) information and (2) impacts.

The impact approach recognizes that, while environmental forces have always affected cultural heritage, effects of climate change are already manifest and are projected to accelerate and intensify. Work within the impacts approach includes research and coordination to identify and respond to these effects. The information approach recognizes that cultural resources provide useful data and profound connections to the history of human interactions with climatic and environmental variability through time. Work within the information approach includes efforts to gather and foster relevant research and to connect it to efforts to address modern climate change (Guedes et al. 2016; Rockman 2015). Applying these two approaches, impacts and information, to the four pillars of NPS climatechange response creates an eight-part concept framework for cultural heritage and climate change (Figure 1; Rockman 2015; Rockman et al. 2016). The NPS developed the concepts listed within this framework iteratively for its Cultural Resources Climate Change Strategy
(Rockman et al. 2016) through consultations with natural and cultural resources specialists, facilities managers, and climate-change specialists within the NPS and with academic colleagues. The listed topics are not exhaustive, but they do illustrate the impacts and information approaches to each of the four pillars of climatechange response.

As set out in this framework, there is science to identify and track impacts of climate change on cultural heritage, and there is science that learns from or works with cultural heritage for an improved and broader understanding of modern climate change. Similarly, for adaptation, there is adaptation of management approaches to address the impacts of climate change on cultural heritage, and there is learning from cultural heritage in order to assist in adapting resource management and society to modern climate change. For example, the impacts side of the science pillar focuses on methods and data that characterize interactions of climatechange phenomena with components of cultural heritage. Materials science compiled in the Atlas of Climate Change Impact on European Cultural Heritage (Sabbioni et al. 2012) is one example of such work; social science research on the impact of climate change on intangible cultural heritage and indigenous peoples is another (e.g., Nakashima et al. 2012). The information side of the science pillar concentrates on cultural heritage's links to paleoecology and paleoclimatic reconstruction (e.g., Sandweiss and Kelley 2012). It also includes use of cultural heritage data to build deeper baseline data on keystone species and the recovery of paleogenetic data that modern-day breeding programs could use (Hambrecht et al. 2017).

The impacts aspect of the adaptation pillar addresses questions of what to do about the impacts of climate change on cultural heritage identified by work in the science pillar. Key parts of this process include scenario planning (see Rose and Star 2013) and development of cultural heritage management options that address climate-change impacts and maintain historical integrity (Markham et al. 2016). Work on the information side of adaptation engages with the dynamics of socionatural systems through time and seeks ways to use these behavioral datasets 


\begin{tabular}{|c|c|c|c|}
\hline \multicolumn{2}{|c|}{ SCIENCE } & \multicolumn{2}{|c|}{ MitiGATION } \\
\hline IMPACTS & INFORMATION & IMPACTS & INFORMATION \\
\hline 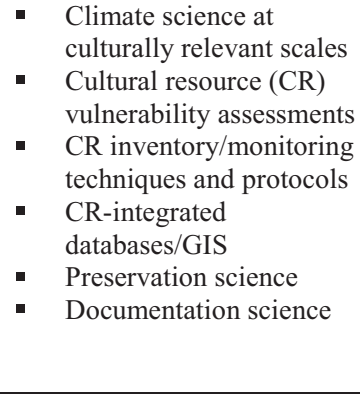 & $\begin{array}{l}\text { Paleoclimate/paleo- } \\
\text { ecology } \\
\text { Traditional } \\
\text { ecological } \\
\text { knowledge } \\
\text { - Social climatic } \\
\text { thresholds } \\
\text { - Shifting baselines } \\
\text { - Past land use and } \\
\text { human impacts on } \\
\text { environments } \\
\text { - Paleogenetics } \\
\end{array}$ & $\begin{array}{l}\text { Integration of } \\
\text { historic buildings } \\
\text { into energy } \\
\text { efficiency plans } \\
\text { Resource } \\
\text { conservation } \\
\text { through historic or } \\
\text { native landscapes } \\
\text { Reduction in carbon } \\
\text { footprint of } \\
\text { management } \\
\text { practices }\end{array}$ & $\begin{array}{l}\text { Past architectural } \\
\text { and landscape } \\
\text { techniques suited to } \\
\text { local environments } \\
\text { Cultural heritage to } \\
\text { conserve/reestablish } \\
\text { sense of place and } \\
\text { community } \\
\text { stewardship }\end{array}$ \\
\hline \multicolumn{2}{|c|}{ ADAPTATION } & \multicolumn{2}{|c|}{ COMMUNICATION } \\
\hline IMPACTS & INFORMATION & IMPACTS & INFORMATION \\
\hline 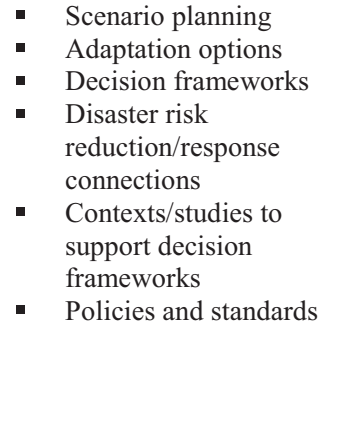 & $\begin{array}{l}\text { - } \begin{array}{l}\text { Identifying examples } \\
\text { of past social } \\
\text { adaptability to } \\
\text { environmental } \\
\text { change }\end{array} \\
\text { Implementing } \\
\text { traditional ecological } \\
\text { knowledge } \\
\text { Relating past } \\
\text { adaptability to } \\
\text { current issues, } \\
\text { methods, and } \\
\text { decisions }\end{array}$ & $\begin{array}{l}\text { Cultural resources } \\
\text { climate change (CR- } \\
\text { CC) literacy } \\
\text { - Dialogue between } \\
\text { impacts and } \\
\text { information in all } \\
\text { pillars } \\
\text { CR-CC links } \\
\text { between managers } \\
\text { (local-international- } \\
\text { tribal) } \\
\text { CR-CC links to } \\
\text { public }\end{array}$ & $\begin{array}{l}\text { Every Place has a } \\
\text { Climate Story: } \\
\text { - Change in material } \\
\text { culture } \\
\text { - Change in } \\
\text { experience and } \\
\text { lifeways } \\
\text { - Lessons in change } \\
\text { from past societies } \\
\text { Origins of the } \\
\text { modern climate } \\
\text { situation }\end{array}$ \\
\hline
\end{tabular}

Figure 1. US National Park Service Concept Framework for Cultural Resources and Climate Change.

as we confront the range of diverse pathways through the Anthropocene. Historical data are not oracular for modern contexts, but they can reveal the details and consequences of change and adaptation for other communities who also had to navigate rapidly changing climates (Cooper and Sheets 2012; Guedes et al. 2016; Nelson et al. 2016; Rockman 2012; van de Noort 2013). As such, cultural heritage provides testing grounds for questions about processes of social change in relation to environmental conditions, as well as inspiration for alternative social, economic, ecological, and other relationships (Rockman 2012).

The distinction between impacts and information for the mitigation and communication pillars is less direct than in science and adaptation, but still relevant if impacts are understood to mean practical and technical approaches while information provides content and meaning. For example, work on the impacts side of mitigation incorporates cultural heritage (particularly the historic built environment and landscapes) into energy efficiency planning (National Trust for Historic Preservation 2011), as well as reductions in the carbon footprint of cultural heritage management itself. On the information side, cultural heritage offers diverse data on the idea of operating with lower energy inputs. This aspect investigates how past cultures managed, for example, climate control inside structures without sophisticated carbon-based energy sources (Burns 1982; Rockman 2015).

Finally, for the communication pillar, the impacts side includes development of communication pathways (between management practitioners at different scales, between management practitioners and the public, etc.), while the information side supplies the content (Rockman 2015; Rockman and Maase 2017). This article is, of course, a product of the communication pillar, focusing on fostering communication within those communities concerned with cultural heritage. The full scope and scale of the effort 
needed to address climate-change threats to cultural heritage is immense. No one organization or institution will be able to engage in all the work necessary. A global effort with communication at its core is required for a majority of the issues to be addressed (Rockman et al. 2016). This article contributes to this effort.

The impacts/information approach to the four pillars of climate-change response places the idea that we can learn from and use the past to help us navigate the present and future as a central part of how and why we value cultural heritage. Concerned researchers increasingly operate with an agenda that foregrounds how the past contributes to the present and future. In this view, climate-change impacts to cultural heritage threaten not only local communities and their intertwined multiscalar identities but also our ability to navigate present-day hazards generated by climate change. One clear case in point is that rising sea levels now threaten to destroy our best examples of how previous cultures negotiated the impacts of rising sea levels (Erlandson 2008). As the NPS Cultural Resources Climate Change Strategy recognizes, archaeology and cultural heritage threatened by anthropogenic climate change are not just victims but part of the solution (Hambrecht et al. 2017; Rockman et al. 2017; Welling et al. 2015).

The NPS framework gives equal weight to the impacts and information approaches, and there are many projects across the globe dealing with various aspects of each of the four pillars. Yet, to date, the majority of the work accomplished in this realm has focused on impacts. This is due to the reality that we cannot learn from cultural heritage that no longer exists. The digest that follows focuses on the impacts aspect in the hope that it will be of immediate utility to resource managers and scholars.

\section{Methods}

Here we illustrate a range of responses around the world to the problem of climate-change impacts on cultural heritage. As one of our priorities was to produce a digest of resources that could be useful to on-the-ground cultural resource managers, all the examples below have either a well-defined methodology or a set of concrete products available for use and/or emulation. Methodologies or products must be or have been in use, and there must be some available literature addressing their efficacy. Finally, in each case these methodologies and products are available free of charge on the web.

We collected data primarily by networking with colleagues and through literature and web surveys using keyword searches. As we were familiar with a core group of the projects discussed here, inquiry began with these and led to a larger network of practitioners. Literature and web searches also provided links to additional projects. The iterative nature of the research process and bounding criteria suggests that, while the results are not exhaustive, they are substantially illustrative of the current state of the field around the world.

We present examples here within the fourpillar framework. Some of the organizations or projects discussed address concepts that fall into more than one of the pillars. To address one major area of overlap, science and communication, we added the category of citizen science. In other areas of overlap, we mention some organizations in more than one section. However, inclusion in only one section does not mean that this is the only area of activity for that organization; rather, it is only an indication of how that organization's work intersected with our search criteria.

\section{Science}

The science pillar focuses on the collection of data and development of techniques that address the broad questions of how climate change affects and will affect cultural heritage resources. In this sense, science includes direct data development, such as through measurement and definition of impacts, and monitoring and surveillance, as well as analysis in the form of vulnerability assessments and data integration, including geospatial analysis. Development of preservation science and treatments also can be included in this pillar.

\section{Climate-Change Impacts on Cultural Heritage}

A number of projects based at academic institutions work on understanding climatechange impacts on cultural heritage. The Noah's 
Ark Project, for example, based at University College London, seeks to define the parameters of climate impacts on cultural heritage, to influence European policy toward recognizing these threats, and to develop tools and mitigation strategies for specific scenarios in which climate change and cultural heritage intersect (Sabbioni et al. 2012). One very valuable and accessible (though not free) product of this is the Atlas of Climate Change Impacts of European Cultural Heritage (Sabbioni et al. 2012). The EU-funded Climate for Culture (2009-2014) project modeled simulations of the possible effects of climate impacts on cultural heritage sites in Europe. This project created software tools as well as syllabi for a variety of training and practical purposes (Climate for Culture 2017). For example, the online engine developed by the project, exDSS, works as a vulnerability assessment generator and a source of adaptive measures. One can input general data on a site of interest, along with data on local threats, and a variety of resources are generated.

The Archéologie, Littoral, et Reffauchement Terrestre project (Archaeology, Coast and Climate Change, ALERT 2017) focuses on climatechange threats to cultural heritage in Brittany, Lower Normandy, the Pas de Loire in France, and Galicia in Spain. This project created a method for generating standardized vulnerability assessments of coastal cultural-heritage sites (Daire et al. 2012; Shi et al. 2012). Researchers tested this method in several regions; it offers a robust example of data collection and processing for the creation of vulnerability assessments.

Focusing on the Nuuk region of Greenland, the REsearch and Management of Archaeological sites IN a changing environment and Society project (REMAINS) is a collaboration between the Greenland National Museum and Archives, the National Museum of Denmark, and the Center for Permafrost (REMAINS 2016). Archaeological remains, especially organic, are under serious threat from thawing permafrost, yet much of the evidence for this threat has been anecdotal. REMAINS measures the damage at a series of sites in a methodical way and generates a variety of risk assessment tools for cultural resource managers in similar climate contexts (Hollesen et al. 2016).

\section{Catastrophic Hazards}

The effects of climate change on cultural heritage manifest themselves across a variety of spatial and temporal scales. One of the most obvious and dramatic is the rapid and catastrophic scale. There are many instances of rapid and catastrophic effects on cultural heritage having little to do with climate change, such as earthquakes, tsunami, and volcanic eruptions. There are, however, others that are clearly related to climate change, for example, flooding and rapid erosion from extreme precipitation. The conjuncture of rising sea levels with more frequent and stronger storms is another. Hurricane Sandy and the resulting damage done to Ellis Island is a recent example of this sort of phenomenon.

A long-standing program in the management of cultural heritage faced with catastrophic conditions is the Institute of Disaster Mitigation for Urban Cultural Heritage at Ritsumeikan University in Kyoto, Japan (Ritsumeikan University 2017). Initially sponsored by UNESCO, the Institute draws on Japan's experience with cultural heritage threats from earthquakes and tsunamis. The Institute is dedicated to education and research centered on threats to urban cultural heritage. They host a number of research projects; for example, they have been building 3D risk maps of the historic city of Kyoto. The institute also hosts an international training course that each year focuses on different aspects of disaster-based threats to urban cultural heritage. In 2015, for example, the international training course focused on "protecting cultural heritage from disaster risks due to earthquakes and floods" (Ritsumeikan University 2015). While not entirely focused on climate-change threats to cultural heritage, such programs substantially overlap with the priorities of those concerned with climate threats to cultural heritage on the catastrophic scale.

\section{Threat-Specific Science}

Several organizations and projects have investigated the effects of specific threats on cultural heritage. In the following cases, these threats result from phenomena that are or will be significantly exacerbated by anthropogenic climate change. 
Most of the public would consider stone to be a very strong material and among the most resistant in the face of changing climates. Yet a number of projects throughout the world examine the impacts of climate change, especially increasing levels of moisture, on historic stone structures and find that stone is not always so strong and permanent. The Oxford Rock Breakdown Lab (Goudie 2016; Goudie and Viles 2016; Viles 2016; Wilhelm, Viles, and Burke 2016; Wilhelm et al. 2016) studies potential impacts on stone, such as the impacts of increasing moisture and the influence of external variables such as vegetation and graffiti on stone structures in changing climates. Given that so many of the most visible world cultural heritage properties are made of stone, this area of study promises to focus the impacts of changing climates onto some of the most visited and publicly valued cultural heritage sites in the world. Unfortunately, this research is revealing alarming vulnerabilities in what had seemed to be the most robust cultural heritage sites.

Fire is a clear and increasing threat to cultural heritage in both dry climates and in the Arctic (Kelly et al. 2013; Mallinis et al. 2016). One project dedicated to this problem is FIRESENSE (Salah et al. 2011), a three-year European collaboration (2009-2012) focused on the Mediterranean. FIRESENSE created a suite of sensors intended to predict conditions of high wildfire potential in areas with high densities of cultural heritage (mostly Classical) sites. The project tested the system in Greece, Turkey, Tunisia, and Italy. Training resources and deliverables describing the different facets of the project are available online. Given the increase in wildfires across many different contexts, desert, arctic and semi-arid, such a study could have applications far outside the Mediterranean.

\section{Adaptation}

Adaptation is the process of answering the question of what is to be done about the specific situations defined by the science. It requires one to identify a range of options and test them within a variety of hypothetical scenarios, from national policy to managerial on-site decision making. As adaptation approaches and techniques are responses to the impacts identified by work in the science pillar, organizations working in one area often also work in the other. This close connection between adaptation and science is reflected below.

Both the Noah's Ark project and the Climate for Culture project generate adaptive responses that arise directly out of their work in the realm of impacts science. Many of these are directed at the needs of conservators and curators dealing with collections and archives. However, a number engage with climate threats to the built environment. Another excellent source for classes and workshops that deal with adaptation techniques is the International Centre for the Study of the Preservation and Restoration of Cultural Property website (ICCROM 2017).

\section{TEK and TREM as Adaptation Pathways}

One innovative adaptation to climate threats to cultural heritage involves the use of traditional ecological knowledge (TEK) and traditional resource and environmental management (TREM) techniques and strategies to inform contemporary management (Goswami 2015). One example comes from the management strategy of Australia's Kakadu National Park (a UNESCO World Heritage Site). While the use of fire in the management of this area shares characteristics with indigenous aboriginal use of fire as a landscape management tool, there are some divergences. For example, current practice uses helicopters to fire specific areas of the landscape. The timing of the fires also differs from aboriginal TREM (Petty, deKoninck, and Orlove 2015; Petty, Isendahl, et al. 2015). Nonetheless, this project supplies a dimension to landscape management that brings the human and historical ecological aspect to the forefront by gaining inspiration from past indigenous uses of fire as a landscape management tool.

Another domestic example of such an approach is work being done in California, which is included here because it is part of a larger project based at the Research Institute for Humanity and Nature (RIHN) in Kyoto, Japan. This project, a collaboration between the RIHN, the University of California, Berkeley, and the California State Parks, combines both the impacts and information aspects of the 
adaptation pillar. As part of a strategy to address climate hazards, a combined cultural anthropological and archaeological approach has recommended the reinstatement of TREM practices. This primarily involves the introduction of anthropogenic fires that periodically clear the landscape of biomass and, in the medium-term and long-term, decrease the chances of potentially more destructive wildfires. The recovery of TREM was done through both archaeological investigations and ethnographic engagement with the ancestral indigenous peoples of the area (Lightfoot et al. 2013; Lightfoot and Lopez 2013). These projects reveal that indigenous peoples used fire as a landscape management tool; understanding how they did so supplies alternative management pathways that recognize human management of natural landscapes is not a solely modern phenomenon. Given the changing conditions of today, such projects illustrate how we can mobilize the past, and TEK, to adapt to rapidly changing conditions.

\section{Mitigation}

Mitigation addresses the reduction of greenhouse gas emissions and the overall environmental footprint of cultural heritage. To date, activity in this area has focused on the historic built environment and cultural landscapes, since historical buildings and landscape maintenance can be energy intensive, while archaeological sites are generally not (although the carbon footprint of archaeological fieldwork does not appear to have received much, if any, attention). In some cases, cultural resource managers have recognized that cultural heritage can assist carbon mitigation efforts, given that historic houses and landscapes often had to incorporate passive environmental controls that managers can identify and restore. Since they do not rely on modern fuels or electricity, passive environmental controls, such as site location and orientation, airflow control, and insulation, can reduce greenhouse gas emissions. Beyond the recognition and use of passive energy management, there is the idea that often "the greenest building is one that already exists" (National Trust for Historic Preservation 2011). This refers to situations in which the creation of a new energy-efficient building could consume more energy, time, and resources than the original building ever wasted. Carbon mitigation in cultural heritage outside of historic buildings and landscapes appears to be a relatively unexplored field.

International organizations such as the World Monuments Fund (WMF) and ICCROM are discussing carbon mitigation in cultural heritage sites through the use of modern techniques as well as through the use of historic passive environmental management methods and TEK. The United Kingdom's Historic England and Historic Environment Scotland both include mitigation within their national plans (Historic England 2013; Historic Environment Scotland 2012). In each case, reduction of the carbon footprint and the increase of energy efficiency in cultural heritage sites are main themes.

In terms of projects focused solely on climate mitigation from the perspective of cultural heritage, one of the most interesting is the Reduced Footprints of Monumental Structures, Landscapes, and Buildings project (ReFoMo 2017). Based in Utrecht, Netherlands, but with partners in Spain, Italy, and Hungary, and part of the private/public EU Climate-KIC initiative, ReFoMo investigates the carbon footprint of cultural heritage and generates strategies to reduce such footprints. ReFoMo also examines the level of demand for climate-based refurbishment of cultural heritage structures as well as the barriers to achieving reduced carbon footprints within these cultural heritage resources. The ReFoMo website contains many of the results of this ongoing project in publicly accessible form. The Climates of Culture project also engaged with the task of mitigation in cultural heritage, though only within built cultural heritage. For example, the April 2014 Climates for Culture Report on Minimizing Energy Consumption Needs of Typical Historic Sites (Case Studies), Revitalization and Enhancement of Historic Climatisation Systems, Use of Alternative Energy Sources (Vyhlidal and Brostrom 2014) describes a number of approaches to lessening energy consumption in historic structures. The report examines the revitalization of original climate control systems (premodern and generally passive) as a way to 
achieve carbon-neutral ventilation and temperature systems in historic buildings.

ReFoMo and Climate for Culture have addressed the carbon footprint of museum collections as well. The Bizot Group, a collection of the world's highest-profile museums, has also addressed this issue through the 2015 Bizot Green Protocol, which provides guidance for the green management of museum collections (National Museums Organization UK 2017).

\section{Communication}

Organizations focused on the sharing of knowledge about the impacts of climate change on cultural heritage are appearing on the international stage, as they are in the United States. This article will not discuss the dialogue around cultural heritage at the level of international climatechange venues such as the UN Framework Convention on Climate Change Conference of the Parties, but instead will discuss archaeologybased organizations engaged in knowledge sharing via professional networks or public outreach.

There are two examples at the level of professional archaeology organizations. The first, Preserving Archaeological Remains in Situ (PARIS), started as an organization concerned with the threats to archaeology and cultural heritage from development and then moved into a concern for climate change-based threats. PARIS has hosted five major conferences since 1996; its most recent, held in Switzerland in 2015, devoted substantial attention to climate threats to cultural heritage. The second, Weather Beaten Archaeology, has emerged solely in response to climate-change threats to archaeology and focuses on threatened coastal cultural heritage. At its first conference, held in Sligo, Ireland, in 2015, examples of coastal cultural heritage that were being destroyed by rising sea levels dominated the conversation.

\section{Communication and Citizen Science Organizations}

An increasing number of programs help communities monitor cultural heritage sites. Many of these include outreach programs that incorporate the ideas of site adaptation and communica- tion. The following North Atlantic programs all enlist public and local community stakeholders as observers as well as active participants in combatting threats to cultural heritage.

\section{SCAPE}

The Scottish Coastal Archaeology and the Problem of Erosion Trust (SCAPE 2017) is a charity based out of the University of St. Andrews, Scotland; its focus is research, promotion, and conservation of Scottish coastal archaeology. Coastal archaeology is arguably on the front lines of climate-change threats to cultural heritage. Archaeologists are witnessing increasing levels of destruction from storm surge, tidal erosion, and melting permafrost across the globe (Erlandson 2012; Fitzpatrick et al. 2015; Hollesen et al. 2016), and organizations such as Weather Beaten Archaeology are a testament to this problem. The SCAPE Trust is at the forefront of the development of innovative and inclusive strategies dealing with this particular threat and serves as a model for similar programs emerging elsewhere.

Among its many innovative projects is Scotland's Coastal Heritage at Risk (SCHARP 2017). In collaboration with Historic Environment Scotland and Local Authority archaeologists, SCAPE did an extensive amount of background work to assess existing archaeological site records and prioritize sites according to a combined metric of vulnerability and significance. SCHARP made this set of at-risk prioritized sites available through a smartphone and tablet app and asked for volunteer citizen archaeologists to use the app to assist with the monitoring of the at-risk sites and identification of new coastal sites. SCHARP recruits local community members to become surveyors as well as monitors of their own coastal archaeological heritage. When they find a new site, volunteers take a photo as well as a GPS point, and write a short description of the site. For sites already recorded, volunteers keep watch and record the condition of the site through time. SCHARP curates and reviews these data and shares them with the National Monuments Record of Scotland (NMRS) as well as Local Authority databases. When assessed together, the data collected through the app record the strength and speed of the destruction of archaeological 
resources on the Scottish coast. This process often leads to the reprioritization of sites based on up-to-date information, thus ensuring better management of the resource.

Another arm of SCHARP is called ShoreDIG. Local communities can nominate a threatened site and then, if chosen, ShoreDIG works with the community to find the most appropriate way for the community to preserve some aspect of the site. Activities have ranged from public archaeological excavations to reconstructions of site components, documentation projects, oral histories and films, and laser scanning used to build 3D interactive models. Professional SCAPE archaeologists lead these projects, but members of the local communities (Dawson 2015) largely staff them.

Any archaeologist or cultural heritage manager reading this will be considering all the ramifications of public access to site information and the issue of looting. By recruiting the public for survey and surveillance, SCAPE increases the visibility of sites but prevents looting by making the local community aware of and invested in the sites. The SCAPE model is supposed to stimulate local community protection of archaeological sites. Applying such an approach in other countries would, of course, require its adaptation to the specific cultural, geographical, demographic, and legal contexts involved.

\section{Other International Citizen Science Efforts}

A number of other citizen science projects for coastal cultural heritage have begun in the United Kingdom and the Republic of Ireland, many inspired by SCAPE. Coastal and Intertidal Zone Archaeological Network in England (CITiZAN 2017), Arfordir in Wales (Arfordir 2017), and Monitoring the Archaeology of Sligo's Coastline in Ireland (MASC 2017) all mobilize the public in order to identify, monitor, and prioritize coastal archaeological sites under threat from increasing erosion from rising sea levels.

Canada's Coastal Archaeological Resources Risk Assessment (CARRA 2017) project in Newfoundland/Labrador identifies at-risk coastal archaeological sites and investigates how to prioritize them for future adaptation efforts.
This project will also survey and examine the cost and effectiveness of current coastal protection strategies employed throughout Newfoundland and Labrador, as well as other parts of Canada, with the goal of creating a database of best practices. Ultimately, case studies of sites under threat will be gathered as a resource for cultural heritage managers across Canada (Pollard-Belsheim et al. 2014).

\section{The Public and Prioritization}

Common to these programs are databases that record the number of visits to specific sites by community participants. Site visit data plus the accompanying social media material that these visits can produce serve as proxies of local community interest in cultural heritage sites. The number of threatened sites is staggering and, given current climate change projections, will continue to increase. One reality of these efforts is recognition that many of the most threatened sites will be lost without our being able to retrieve any information from them. The NPS 2014 Director's Policy Memo (National Park Service 2014:5) sets the stage for cultural resources management in the US under these conditions:

Recognize Loss: We will ensure that our management options recognize the potential for loss. Responsible stewardship requires making choices that promote resilience and taking sustainable management actions. Funding temporary repairs for resources that cannot, because of their location or fragility, be saved for the long term, demands careful thought. Managers should consider choices such as documenting some resources and allowing them to fall into ruin rather than rebuilding after major storms. Such decisions for loss cannot be made lightly nor without appropriate consultation and compliance. They must incorporate interdisciplinary research and should be coordinated on a consistent and Service-wide basis.

In this setting, one of the most important activities of cultural resource managers will be coordinating prioritization among local communities, scientific and academic groups, the tourism 
industry, and local governments to address questions such as which sites can and should be saved, or at least recorded, and, which, regrettably, can be written off. If the hazards facing only a small fraction of threatened cultural heritage sites, especially coastal sites, can be addressed, then creating fair and effective processes for determining the sites to which limited resources, both financial and human, should be applied is of the utmost importance. National funding venues such as the US National Science Foundation are already seeing an increase in requests for funds to save or at least record threatened sites and, in response, are asking that archaeologists create prioritization strategies. The citizen science projects discussed in the previous section all generate data that are being used to prioritize threatened sites and should serve as a model for understanding the levels of value local communities see in their own cultural heritage.

\section{Conclusion}

Taken together, these projects from around the world demonstrate that, in mobilizing to meet the challenge of climate-change threats to cultural heritage, the US and particularly the NPS are joining a growing international community. This is a creative community that has established important baseline data and adaptive responses in diverse areas, ranging from the effects of climate change on heritage and approaches to management and mitigation, to public engagement in monitoring and decision making. The NPS stands to learn (and indeed has learned) from the experiences of this international community.

In turn, the US and the NPS bring community experience managing the effects of and initial responses to climate change within the great diversity of American cultural heritage and environments (see case studies in Holtz et al. 2014). The NPS can contribute knowledge based on its long experience in visitor interaction and interpretation and can help improve the connections between the impacts of climate change on cultural heritage and our capacity to learn from them. As noted above, this international review has focused on impacts. Some work on information was identified during the review that led to this paper (Rockman et al. 2016), but overall these efforts are not as well developed or integrated as approaches to impacts. The information approach addresses many of the challenges climate change presents, from better models and understandings of the processes of human social change over time to the stories and tangible heritage that support communities in maintaining identities and other important connections in the midst of change. Although the impacts aspect of each of the four pillars is of the utmost importance in the effort to manage climate-change threats to cultural heritage, the information aspect has perhaps the greatest potential to supply ideas, stories, and data that can assist in our species' navigation through contemporary anthropogenic climate change.

Climate change-based threats to cultural heritage are not waiting on the horizon but are with us now, and their impacts are increasing in geographical range as well as intensity. More attention is being paid to this issue around the world, as this article makes clear. Moving forward, priorities that will drive efforts to deal with climatechange threats to cultural heritage should include the following: (1) greater knowledge sharing between stakeholders at an international level; (2) more communication to the various publics (local, regional, national, and international) on this issue; (3) the development of tools that local communities and cultural resource managers can use to monitor and prioritize threatened sites; and (4) the allocation of more resources by funding agencies, universities, governmental and nongovernmental organizations, and private foundations toward projects dealing with the effects of climate change on cultural heritage.

The good news is that there is action on all these priorities (though less so on the last one). Irrevocable losses of cultural heritage and key environmental and archaeological data due to the effects of anthropogenic climate change are already taking place. Future generations will judge us harshly if we do not engage seriously and effectively to save our "burning libraries of the past" (McGovern 2016). As this issue increasingly moves to the front of both the public and policy consciousness and as archaeologists and cultural resource managers produce strategies to deal with this growing problem, we must realize that it is not one that can be 
effectively engaged with by any one organization or nation. Therefore, this article is intended as a small step toward knowledge sharing between the various international projects engaging with this issue and the US audience of local communities, cultural resource managers, and researchers impacted by this phenomenon.

Acknowledgments. National Science Foundation SEES Grant \#40B85.00.01 "Global Long-term Human Ecodynamics Research Coordination Network: Assessing Sustainability on the Millennial Scale" funded much of the travel and networking that produced significant data for this article. The National Park Service supported research and writing incorporated into this article through the Chesapeake Watershed Cooperative Ecosystems Study Unit (CESU) Cooperative Agreement No. P11AC3080, Task Agreement P13AC01416. This article is the product of collaboration between the UMDCP, the University of Maryland College Park Department of Anthropology, and the NPS Climate Change Adaptation Coordinator for Cultural Resources.

Data Availability Statement. Data presented in this article are available as part of the NPS Cultural Resources and Climate Change Strategy document, available at https://www.nps.gov/subjects/climatechange/ culturalresourcesstrategy.htm.

\section{References Cited}

Archéologie, Littoral, et Reffauchement Terrestre Project (ALeRT)

2017 Archéologie, Littoral, et Reffauchement Terrestre Project (ALeRT). Electronic document, https: //alert-archeo.org/, accessed July 15, 2015.

Arfordir

2017 Arfordir Coastal Heritage Project. Electronic document, http://www.ggat.org.uk/arfordir/, accessed January $29,2015$.

Australian Government, Department of Climate Change and the Department of Water, Heritage, and the Arts

2009 Implications of Climate Change for Australia's World Heritage Properties: a Preliminary Assessment. Electronic document, http://www.environment.gov.au/ resource/implications-climate-change-australiasworld-heritage-properties-preliminary-assessment, accessed March 30, 2015.

Burns, John A.

1982 Energy Conserving Features Inherent in Older Homes. US Government Printing Office, Washington, DC.

CARRA

2017 Coastal Archaeological Resources Assessment (CARRA). Electronic document, https://carra-nl.com/, accessed February 20, 2015.

Cassar, May

2005 Climate Change and the Historic Environment. Centre for Sustainable Heritage, University College Lon- don, London. Electronic document, http://discovery.ucl. ac.uk/2082/1/2082.pdf, accessed December 15, 2015.

CITiZAN

2017 Coastal and Intertidal Zone Archaeological Network (CITiZAN). Electronic document, http://www.citizan. org.uk/, accessed July 24, 2017.

Climate for Culture

2017 Climate for Culture. Electronic document, https: //www.climateforculture.eu/index.php?inhalt=home, accessed June 12, 2015.

Cooper, Jago, and Payson Sheets

2012 Surviving Sudden Environmental Change: Answers from Archaeology. University Press of Colorado, Boulder.

Daire, Marie-Yvane, Elias Lopez-Romero, Jean-Noël Proust, Hervé Regnauld, Soazig Pian, and Benheng Shi

2012 Coastal Changes and Cultural Heritage (1): Assessment of the Vulnerability of the Coastal Heritage in Western France. The Journal of Island and Coastal Archaeology 7:168-182.

Dawson, Tom

2015 Taking the Middle Path to the Coast: How Community Collaboration Can Help Save Threatened Sites. In The Future of Heritage as Climates Change: Loss, Adaptation and Creativity, edited by David Harvey and Jim Perry, pp. 248-268. Taylor and Francis, London.

Erlandson, Jon M.

2008 Racing a Rising Tide: Global Warming, Rising Seas, and the Erosion of Human History. The Journal of Island and Coastal Archaeology 3:167-169.

2012 As the World Warms: Rising Seas, Coastal Archaeology, and the Erosion of Maritime History. Journal of Island Conservation 16:137-142.

Fitzpatrick, Scott M., Torben C. Rick, and Jon M. Erlandson 2015 Recent Progress, Trends, and Developments in Island and Coastal Archaeology. The Journal of Island and Coastal Archaeology 10:3-27.

Goswami, Rahul

2015 How Intangible Cultural Heritage Adapts to a Changing World. World Heritage 77:30-36.

Goudie, Andrew S.

2016 Quantification of Rock Control in Geomorphology. Earth-Science Reviews 159:374-387.

Goudie, Andrew S., and Heather A. Viles

2016 Geomorphology in the Anthropocene. Cambridge University Press, Cambridge.

Guedes, Jade, Stefani Crabtree, Kyle Bocinsky, and Tim Kohler

2016 Twenty-First Century Approaches to Ancient Problems: Climate and Society. Proceedings of the National Academy of Sciences 113(51):14483-14491.

Hambrecht, George, Cecilia Anderung, Seth Brewington, Andrew Dugmore, Ragnar Edvardsson, Francis Feeley, Kevin Gibbons, Ramona Harrison, Megan Hicks, Guðbjörg Olafsdóttir, Marcy Rockman, Konrad Smiarowski, Richard Streeter, Vicki Szabo, and Thomas McGovern

2017 DONOP: Archaeological Sites as Distributed LongTerm Observing Networks of the Past. Manuscript on file, Anthropology Department, University of Maryland, College Park.

Harvey, David, and Jim Perry

2015 The Future of Heritage as Climates Change: Loss, Adaptation and Creativity. Routledge, New York. 
Historic England

2013 Assessment of Heritage at Risk from Environmental Threat. Electronic document, https://historicengland. org.uk/images-books/publications/assessmentheritage-at-risk-from-environmental-threat/, accessed March 20, 2015.

Historic Environment Scotland

2012 A Climate Change Action Plan for Historic Scotland, 2012-2017. Electronic document, https://www. historicenvironment.scot/media/2611/climate-changeplan-2012.pdf, accessed March 22, 2015.

Hollesen, Jørgen, Henning Matthiesen, Anders Bjørn Møller, Andreas Westergaard-Nielsen, and Bo Elberling

2016 Climate Change and the Loss of Organic Archaeological Deposits in the Arctic. Scientific Reports 6. Electronic document, http://www.ncbi.nlm.nih.gov/ pmc/articles/PMC4928077/, accessed December 10, 2016.

Holtz, Debra, Adam Markham, Kate Cell, and Brenda Ekwurzel

2014 National Landmarks at Risk: How Rising Seas, Floods, and Wildfires are Threatening the United States' Most Cherished Historic Sites. Union of Concerned Scientists. Electronic document, http://www.ucsusa. org/global_warming/science_and_impacts/impacts/ national-landmarks-at-risk-from-climate-change. html\#.WLCQFG_yvcs, accessed September 12, 2015.

\section{ICCROM}

2017 Disaster and Risk Management. Electronic document, http://www.iccrom.org/priority-areas/disasterrisk/, accessed February 15, 2017.

Kelly, Ryan, Melissa L. Chipman, Philip E. Higuera, Ivanka Stefanova, Linda B. Brubaker, and Feng Sheng $\mathrm{Hu}$

2013 Recent Burning of Boreal Forests Exceeds Fire Regime Limits of the Past 10,000 Years. Proceedings of the National Academy of Sciences 110(32):1305513060.

Lightfoot, Kent G., Rob Q. Cuthrell, Cristie, M. Boone, Roger Byrne, Andreas S. Chavez, Laurel Collins, Alicia Cowart, Rand R. Evett, Paul V. A. Fine, Diane GiffordGonzalez, Mark G. Hylkema, Valentin Lopez, Tracy M. Misiewicz, and Rachel E. B. Reid

2013 Anthropogenic Burning on the Central California Coast in Late Holocene and Early Historical Times: Findings, Implications, and Future Directions. California Archaeology 5:371-390.

Lightfoot, Kent G., and Valentin Lopez

2013 The Study of Indigenous Management Practices in California: An Introduction. California Archaeology 5:209-219.

McGovern, Thomas H.

2016 Endangered Environmental Archives in the North Atlantic, Crisis and Response. Paper given at the 81st Annual Meeting of the Society for American Archaeology, Orlando, Florida.

Mallinis, Giorgos, Ioannis Mitsopoulos, Esteban Beltran, and Johann Goldammer

2016 Assessing Wildfire Risk in Cultural Heritage Properties Using High Spatial and Temporal Resolution Satellite Imagery and Spatially Explicit Fire Simulations: The Case of Holy Mount Athos, Greece. Forests 7(2): 46.

Markham, Adam, Elena Osipova, Kathryn Lafrenz Samuels, and Astrid Caldas
2016 World Heritage and Tourism in a Changing Climate. United Nations Environment Programme, Nairobi, Kenya and United Nations Educational, Scientific and Cultural Organization, Paris, France. Electronic document, http://www.ucsusa.org/global-warming/globalwarming-impacts/world-heritage-tourism-sitesclimate-change-risks\#.WPevPWcpCUk, accessed August 23, 2016.

Markham, Adam, and Jeana Wiser

2015 A Heritage Coalition's Call to Action' on Climate Change and Cultural Heritage. In Forum Journal, 29:19-23. National Trust for Historic Preservation. Electronic document, http://muse.jhu.edu/journals/ forum_journal/v029/29.4.markham.html, accessed March 15, 2016.

Marzeion, Ben, and Anders Levermann

2014 Loss of Cultural World Heritage and Currently Inhabited Places to Sea Level Rise. Environmental Research Letters 9:034001.

MASC

2017 Managing the Archaeology of Sligo's Coastline (MASC). Electronic document, https://themascproject. wordpress.com/, accessed July 24, 2017.

Morgan, Marissa, Marcy Rockman, Caitlin Smith, and Alison Meadow

2016 Climate Change Impacts on Cultural Resources. Cultural Resources Partnerships and Science. National Park Service, Washington, DC.

Nakashima, Douglas, Kirsty Galloway McLean, Hans Thulstrup, Ameyali Ramos Castillo, and Jennifer Rubis

2012 Weathering Uncertainty: Traditional Knowledge for Climate Change Assessment and Adaptation. UNESCO, Paris.

National Museums Organization UK

2017 Bizot Green Protocol. Electronic document, http://www.nationalmuseums.org.uk/what-we-do/ contributing-sector/environmental-conditions/, accessed August 15, 2016.

National Park Service

2010 National Park Service Climate Change Response Strategy. National Park Service Climate Change Response Program, Fort Collins, Colorado.

2014 Climate Change and Stewardship of Cultural Resources. US DOI National Park Service Policy Memorandum 14-02. Electronic document, http://www.nps. gov/policy/PolMemos/PM-14-02.htm, accessed April 20, 2015.

National Trust for Historic Preservation

2011 The Greenest Building: Quantifying the Environmental Value of Building Reuse. Electronic document, http://www.preservationnation.org/information-center/ sustainable-communities/green-lab/lca/The Greenest_Building_lowres.pdf, accessed April 13, 2015.

Nelson, Margaret C., Scott E. Ingram, Andrew J. Dugmore, Richard Streeter, Matthew A. Peeples, Thomas H. McGovern, Michelle Hegmon, Jette Arneborg, Keith W. Kintigh, Seth Brewington, Katherine A. Spielmann, Ian A. Simpson, Colleen Strawhacker, Laura E. L. Comeau, Andrea Torvinen, Christian K. Madsen, George Hambrecht, and Konrad Smiarowski

2016 Climate Challenges, Vulnerabilities, and Food Security. Proceedings of the National Academy of Sciences 113(2):298-303. 
Petty, Aaron M., Vanessa deKoninck, and Ben Orlove 2015 Cleaning, Protecting, or Abating? Making Indigenous Fire Management 'Work' in Northern Australia. Journal of Ethnobiology 35:140-162.

Petty, Aaron M., Christian Isendahl, Hannah BrenkertSmith, David J. Goldstein, Jeanine M. Rhemtulla, Syed Ajijur Rahman, and Tyhra C. Kumasi

2015 Applying Historical Ecology to Natural Resource Management Institutions: Lessons from Two Case Studies of Landscape Fire Management. Global Environmental Change 31:1-10.

Pollard-Belsheim, Ariel, Marc Storey, Christina Robinson, and Trevor Bell

2014 The CARRA Project: Developing Tools to Help Heritage Managers Identify and Respond to Coastal Hazard Impacts on Archaeological Resources. Paper presented at the 2014 IEEE Oceans Conference, St. John's, Newfoundland.

REsearch and Management of Archaeological sites IN a changing environment and Society (REMAINS)

2017 Remains of Greenland. Electronic document, http: //www.remains.eu/, accessed July 22, 2016.

Ritsumeikan University

2017 Institute for Disaster Mitigation for Urban Cultural Heritage. Electronic document, http://r-dmuch.jp/en/, accessed August 20, 2015.

Rockman, Marcy

2012 The Necessary Roles of Archaeology in Climate Change Mitigation and Adaptation. In Archaeology in Society: Its Relevance in the Modern World, edited by Marcy Rockman and Joe Flatman, pp. 193-215. Springer, New York

2015 An NPS Framework for Addressing Climate Change with Cultural Resources. The George Wright Forum 32(1):37-50.

Rockman, Marcy, and Jakob Maase

2017 Every Place has a Climate Story: Finding and Sharing Climate Change Stories with Cultural Heritage. In Public Archaeology and Climate Change, edited by Tom Dawson, Courtney Nimura, Elías LópezRomero, and Marie-Yvane Daire, in press. Oxbow Books, Oxford.

Rockman, Marcy, Marissa Morgan, Sonya Ziaja, George Hambrecht, and Alison Meadow

2016 Cultural Resources Climate Change Strategy, Cultural Resources Partnerships and Science and Climate Change Response Program, National Park Service, Washington, DC.

Rose, Matthew, and Jonathan Star

2013 Using Scenarios to Explore Climate Change: A Handbook for Practitioners. Climate Change Response Program, National Park Service, Fort Collins, Colorado.

Sabbioni, C, Peter Brimblecombe, May Cassar, and Noah's Ark (Project)

2012 The Atlas of Climate Change Impact on European Cultural Heritage: Scientific Analysis and Management Strategies. Anthem, New York.

Salah, Albert Ali, Jungong Han, Eric Pauwels, and Paul de Zeeuw

2011 Multimodal Monitoring of Cultural Heritage Sites and the FIRESENSE Project. In Proceedings of the 4th International Symposium on Applied Sciences in Biomedical and Communication Technologies, 152. ACM. Electronic document, http://dl.acm.org/citation. cfm?id=2093850, accessed October 25, 2015.
Sandweiss, Daniel, and Alice Kelley

2012 Archaeological Contributions to Climate Change Research: The Archaeological Record as a Paleoclimatic and Paleoenvironmental Archive. Annual Review of Anthropology 41:371-391.

SCAPE

2017 Scottish Coastal Archaeology and the Problem of Erosion (SCAPE). Electronic document, http://www. scapetrust.org/, accessed January 15, 2014.

\section{SCHARP}

2017 Scottish Coastal Heritage at Risk (SCHARP). Electronic document, http://scharp.co.uk/, accessed January 15, 2014.

Schupp, Courtney, Marcy Rockman, Jeneva Wright, and Karen Mudar

2016 Cultural Resources. In Coastal Adaptation Strategies Handbook, edited by Rebecca L. Beavers, Amanda L. Babson, and Courtney A. Schupp, pp. 51-69. National Park Service, Washington, DC.

Scott, Daniel, C. Michael Hall, and Stefan Gössling

2016 A Report on the Paris Climate Change Agreement and Its Implications for Tourism: Why We Will Always Have Paris. Journal of Sustainable Tourism 24:933-948.

Shi, Benheng, Jean-Noël Proust, Marie-Yvane Daire, Elias Lopez-Romero, Hervé Regnauld, and Soazig Pian

2012 Coastal Changes and Cultural Heritage (2): An Experiment in the Vilaine Estuary (Brittany, France). The Journal of Island and Coastal Archaeology 7:183199.

Union of Concerned Scientists

2015 The Pocantico Call to Action on Climate Impacts and Cultural Heritage. Electronic document, http:// www.ucsusa.org/sites/default/files/attach/2016/ 04/Pocantico-Call-to-Action-on-Climate-ImpactsCultural-Heritage-4-11-2016.pdf, accessed December $10,2015$.

\section{US ICOMOS}

2017 Climate Change and Heritage. Electronic document, http://www.usicomos.org/knowledgeexchange/ climate-change-and-heritage/, accessed Feb 2, 2017.

van de Noort, Robert

2013 Climate Change Archaeology: Building Resilience from Research in the World's Coastal Wetlands. Oxford University Press, Oxford.

Viles, Heather

2016 Technology and Geomorphology: Are Improvements in Data Collection Techniques Transforming Geomorphic Science? Geomorphology 270:121-133.

Vyhlidahl, Tomas, and Tor Brostrom

2014 Report on Minimizing Energy Consumption needs of Typical Historic Sites (Case Studies), Revitalization and Enhancement of Historic Climatisation Systems, Use of Alternative Energy Sources. Climate for Culture, Electronic document, http://www.climateforculture. eu/index.php?inhalt=furtherresources.projectresults, accessed March 20, 2016.

Welling, Leigh, Marcy Rockman, James Watson, Brendan Mackey, and Andrew Potts

2015 The Role of World Heritage Sites in a Changing Climate. World Heritage Magazine 77:4-13.

Wilhelm, Katrin, Heather Viles, Órlaith Burke, and J. Mayaud

2016 Surface Hardness as a Proxy for Weathering Behaviour of Limestone Heritage: A Case Study on Dated Headstones on the Isle of Portland, UK. Environmental Earth Sciences 75:1-16. 
World Heritage Commission UNESCO

2017 Climate Change and World Heritage. Electronic document, http://whc.unesco.org/en/climatechange/, accessed January 12, 2017.

\section{Note}

1. Use of the term mitigation here follows the Intergovernmental Panel on Climate Change (IPCC) to refer to the reduction of greenhouse gas emissions and to related concepts of energy efficiency and sustainability. This usage is in contrast to its common use in cultural resources management, where it generally refers to the reduction of adverse effects of human actions on cultural heritage.

Submitted November 20, 2016; Revised March 26, 2017; Accepted March 27, 2017 